\title{
Position Paper Number 1 for the Workshop "Towards Criteria of Sustainability and Social Meaningfulness in Development": Instrumental Reason as a Hindering Factor for Meaningful Technology Design
}

\author{
Wolfgang Hofkirchner \& Robert M. Bichler
}

UTI - Unified Theory of Information Research Group, [www.uti.at], wolfgang.hofkirchner@tuwien.ac.at, robert.bichler@uti.at

$\mathrm{T}$ raditionally, there has been a distinction between applied sciences and basic sciences which - so is a widely shared believe - is getting blurred now. The image of an engineer employed in a private lab and taking orders from his employer that is in sharp contrast to the image of an academic just satisfying his curiosity is said to be oldfashioned and outdated. It is true that scientists enjoy freedom of research within given financial, policy and other constraints. But this is rather due to the fact that research and development starting since the last quarter of the last century have been streamlined world-wide according to neoliberal economic policies of liberalization, privatization, and deregulation than to the general statement that the academic system at any time is part of society and thus responsive, be it in a direct or an indirect manner, to historically developing societal needs. Otherwise one could not explain why in developed and thus rich countries many disciplines, in particular within the humanities and social sciences, are publicly stigmatized and said to be nice, but useless, and suffer cuts and total suspensions. Shortsighted economic interest that has taken command in academic affairs. This neolibral paradigm has been exported into the rest of the world. Via public and private transnational funding agencies, such as for example the European Research Framework Programme or The Bill and Melinda Gates Foundation, a neoliberal streamlining of academia more and more takes place on a global scale with the hegemonic goal of creating a global economic output-oriented understanding of research and development. Instrumental reason therefore serves as the basic worldview that underlies research and funding policies. Science and research are undergoing a colonialization process, in which instrumental rationality spills from the economic sub-system over to other areas of life and "achieves dominance there at the expense of moral-practical and aestheticalpractical rationality" (Habermas, 1987, p. 304). Lenin argued that under imperialism, major companies dominate the economy and that capital struggles "for the sources of raw materials, for the export of capital, for 'spheres of influence,' i.e., for spheres of good business, concessions, monopolist profits, and so on; in fine, for economic territory in general" (Lenin,1917, p. 266). Lenin incorrectly assumed that such a form of imperialism is the highest stage of capitalism. As one can witness today, capital also achieves dominance in the area of intellectual work, which is transformed into exploitable intellectual capital. We are observing a shift from industrial capitalism towards informational capitalism or, in terms of the European Union, towards a "knowledge economy". "The 7th Framework Programme is conceived to become the backbone in the construction of a European knowledge economy" (Commission of the European Communities 2006: 17). For the $E U$, the industry is the main driving force for innovations: "The 7th Framework Programme is tailored to better meet industry's needs. [...] Actions to support research for SMEs carried out by universities and research centres will be scaled up significantly. [...] Large initiatives of industrial and technological research at European scale will be launched in a selected number of areas of particular relevance for the EU. In 
addition, industry participation in all funding schemes will be encouraged and special attention will also be made to encourage industry to more actively contribute to the Networks of Excellence" (Commission of the European Communities, 2006, p. 8).

Thus it makes still sense to distinguish between business-driven development of academia and technology and l'art pour l'art activities.

Given the confines of economic profitability and competitiveness, the credo of technocracy is in force that goes: "realize everything that is feasible". Thereby it is falsely presupposed that everything feasible (again, taken for granted it is economically reasonable) is desirable too and hence a reflective, and that a theoretical deliberation of norms, values, morals is not needed or, at best, is replaced by a posteriori, empirical inquiries about the acceptance of technology by users. The idea that empiricism should replace basic, theoretical research is more and more gaining ground and manifests in the way research proposals are set up, as well as in the criteria for acceptance of papers in renowned journals and project proposals. In fact, this detracts from taking into account problems that are more fundamental than those of profitability. However, the current financial crisis that brought about the current economic crisis does question the current neoliberal system and its belief in the free market. In doing so, it makes the quest for a "good society" topical. And indeed, the attention that is given to the issue of a "good society" has recently been rising. Suffice to mention that, in the political field, ten years after Tony Blair and Gerhard Schröder produced their declaration of the European "third way" in June 1999, British and German Social Democrats invite to a debate on "Building the Good Society" in Europe (Cruddas \& Nahles, 2009), or that, in the academic field, there is a trend to base good life research issues being investigated in connection with technologies more and more upon considerations of what is the good society. In that vein for example the director of the European Division of the International Association of Computing and Philosophy, Philip Brey, gave a talk at the Seventh
European Conference on Computing and Philosophy 2009 on the topic "The Proper Role of Information Technology in a Good Society". We consider bringing this topic on the agenda of the academic as well as the political debate as a first positive signal and we have the impression that there has been growing awareness that technological and economical determinism are too myopic. The belief in technological progress, which per se entails social progress, seems to be slowly vanishing.

In our vision, the "good society" must serve as point of departure. A good society, given the global challenges, can be defined as a society that is

$>$ capable of making use of knowledge

$>$ for fighting the dangers of breakdown due to anthropogenic causes

$>$ on a global scale.

Thus we get (1) informationality, (2) sustainability, and (3) globality as essentials for a "good society" which then might be termed Global Sustainable Information Society (Hofkirchner et al., 2007).

That is, we suggest the most universal value to be met by a good society is sustainability, which denotes a society's ability to perpetuate its own development. Sustainability in that senses is conceived as a complex phenomenon, which includes various aspects that need to be achieved in a Gobal Sustainable Information Society (GSIS), such as individual well-being, security, freedom, and self-determination just like collective dimensions such as wealth for all, social security for all, political participation for all, or health and education for all (Fuchs, Blachfellner \& Bichler, 2007, p. 304).

To make this more concrete, we suggest that the notion of sustainability should be broken down into

$>$ a social part, called social compatibility, which is inclusiveness and fairness - to be broken down, in turn, into

- equality in cultural terms,

- political freedom and

- solidarity in the economy -,

$>$ an ecological part, called environmental compatibility, and 
$>$ a technological part, called technological compatibility, by which we mean a balanced relationship of new with old technologies - to be broken down, again, into usefulness, usability, efficiency, reliability, security, safety and other values.

This approach is normative, but doing justice to the factual at the same time. For it includes not only an account of the potential that is given with the actual, but also an evaluation of the potential that sorts out the desired. Thus ICTs and Society in the perspective of the GSIS vision embraces an ascendance from the potential given now to the actual to be established in the future as well as an ascendance from the less good now to the better then which altogether yields the Not-Yet in critical theorist Ernst Bloch's sense (1967). It identifies facilitators and inhibitors of a good society.

The vision of the GSIS does not orient towards a utopian "nowhere", but searches for real possibilities, that is, possibilities that are anchored in reality. They are concrete and demonstrate that the search for a good society, that is, a better society, is not in vain. Those realised possibilities can be envisioned as the foreshadowing of the better society.

It is worth noting that it is only a vision of the good society like the GSIS that gives reason to technological developments that are senseless in themselves unless coupled to humane values which make them a means to an end. Without such an end they would be meaningless.

Contemporary societies are based on many contradictions, for example between self-determination and heteronomy, or inclusion and exclusion. Technological applications foster co-operation and competition for rationalizing the accumulation of economic, political and cultural capital. In the information society, or "informational capitalism", social systems and structures are increasingly shaped by knowledge and ICTs (Bichler, Fuchs \& Raffl, 2008, p. 158). Technology does not follow predictable, mechanically determined and one-sided effects, but a set of multiple antagonistic economic, political, and cultural tendencies, and therefore causes opportunities and risks at the same time.

Therefore, technological applications are to be questioned, and the question is: are they apt to serve the purpose of a GSIS? Actually, the process of design is to start with identifying a societal problem and to be continued with the search for appropriate applications (and not the other way round as is done under technocratic premises). These applications must be continuously evaluated and, if needed, adopted to changing societal circumstances and demands. A neverending circle of human centred design evaluation - re-design, always based on societal problems and needs, is central to lay the basis for a Sustainable Information Society, which is not following the neoliberal economic imperative.

\section{References}

Bichler, R. M. \& Fuchs, C. \& Raffl, C. (2008). Perspectives of Cyberethics in the Information Society. In N. Billias \& A. B. Curry (Eds), Framing Evil. Portraits of Terror \& the Imagination (pp. 153-162). Oxford: Interdisciplinary-Press. Bloch, E. (1967). Das Prinzip Hoffnung. 3 vols. Frankfurt: Suhrkamp.

Commission of the European Communities (2006). Communication from the Commission: Building the ERA of Knowledge for Growth. 
Cruddas, J. \& Nahles, A. (2009). Building the Good Society, The Project of the Democratic Left. Retrieved November 15, 2009, from http://www.goodsociety.eu/wp-content/uploads/2009/04/building_the_good_society.pdf

Fuchs, C. \& Blachfellner, S. \& Bichler, R. M. (2007). The Urgent Need for Change: Rethinking Knowledge and Management. In C. Stary \& F. Barachini \& S. Hawamdeh (Eds.), Knowledge Management: Innovation, Technology and Cultures. Series on Innovation and Knowledge Management - Vol. 6. Proceedings of the 2007 International Conference on Knowledge Management (pp. 293-307). New Jersey, London, Singapore: World Scientific.

Habermas, J. (1987). The Theory of Communicative Action: the Critique of Functionalist Reason (Vol. 2). Cambridge: Polity Press.

Hofkirchner, W., Fuchs, C., Raffl, C., Schafranek, M., Sandoval, M. \& Bichler, R. M. (2007). ICTs and Society: The Salzburg Approach. Towards a Theory for, about, and by means of the Information Society (Research Paper No. 3 , ISSN 1990-8563). Salzburg: University of Salzburg, ICT\&S Center. Retrieved November 15, 2009, from http://icts.sbg.ac.at/media/pdf/pdf1490.pdf

Lenin, V. I. (1917). Imperialism, the highest stage of capitalism. In H. M. Christman (Ed.) Essential works of Lenin (pp. 177270). New York: Dover.

\section{About the Authors}

\section{Wolfgang Hofkirchner}

Wolfgang Hofkirchner is consecutively Visiting Professor at the University of León, Spain, supporting the project 'BITrum' on information concepts and finalizing a book on the Unified Theory of Information, and Visiting Professor at the Open University of Catalonia, Barcelona, where he stays at the Interdisciplinary Internet Institute (IN3), organizing the annual meeting of the 'ICTs and Society Network (http://www.icts-and-society.net). He also works on a book about information society theory. He is editor of tripleC, an open access journal for the Global Sustainable Information Society, head of the Unified Theory of Information Research Group and director of the Bertalanffy Center for the Study of Systems Science. Address: Institute for Design and Technology Assessment, Favoritenstraße 9/E187, 1040 Vienna, Austria. [email: wolfgang.hofkirchner@tuwien.ac.at]

\section{Robert M. Bichler}

Robert M. Bichler is lecturer at the Shanghai International Studies University (SISU) and member of the Unified Theory of Information (UTI) Research Group - Association for the Advancement of Information Sciences. Prior he was a research fellow and lecturer at the ICT\&S Center at the University of Salzburg. Address: Shanghai International Studies University, German Department, 550 Da Lian Road (W), Shanghai 200083, P.R. China. [email: robert.bichler@uti.at] 